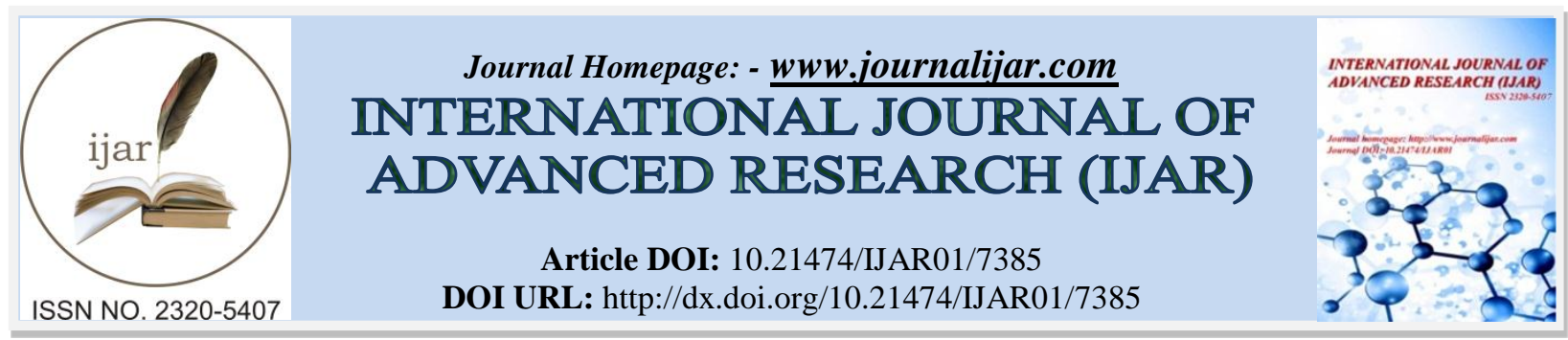

RESEARCH ARTICLE

\title{
ANALYSIS OF INNOVATIVE STRATEGIES INFLUENCE ON BUSINESS GROWTH OF SMES IN NAIROBI COUNTY, KENYA: CASE OF SMES IN GIKOMBA MARKET.
}

Justice J. Mutua Nzioki and Dr. Lucy Kibe.

School Of Business and Economics, Mount Kenya University.

\section{Manuscript Info}

Manuscript History

Received: 10 May 2018

Final Accepted: 12 June 2018

Published: July 2018

Keywords:-

Small and medium size enterprises

(SMEs), business growth and innovative strategies.

\begin{abstract}
In modern societies the role of SMEs in economic development, innovation, and gross domestic product (GDP) is evident. The Government of Kenya through Vision 2030 has tried to put an enabling environment to help nurture and grow smes. This research addresses a key determinant of SMEs business growth. SMEs have contributed to over $60 \%$ of jobs and statistics indicate that most of these smes are in the brink of failure as only two out of every five SMEs make it through past the first few months. The research specific objective was to assess the influence of innovative strategies on SME business growth. The target population was six hundred (600) smes. A sample size of one hundred and twenty (120) smes was selected using stratified random sampling. The research adopted a descriptive research design. Semi structured questionnaires and interview guides were used to collect data. Descriptive statistical techniques as well as a Statistical Package for Social Sciences (SPSS 21.0) were used to analyze collected data. The research revealed the existence of a positive relation between training and SMEs business growth. As the national and county governments seek to promote entrepreneurship and provides employment to the youth, there is need to invest in providing training to the youths and SME operators in general while creating an ease in business registration and operation. Entrepreneurs and the government should invest in training initiatives to boost SME entrepreneurial skills.
\end{abstract}

Copy Right, IJAR, 2018,. All rights reserved.

\section{Introduction:-}

The world globally, regionally and locally has indicated great concern on SME business performance and growth. Previous reports indicate that SMEs are the backbone of any economy worldwide yet many have either collapsed or are in the verge of failing. According to a World Bank Economic Report (2014), majority of emerging economies boast of over $40 \%$ SMEs. SMEs have a notable effect on resource utilization and distribution, job creation, government revenue generation, as well as income stability (Fida, 2008). In many developed countries, SMEs employ about two-thirds of their population and a case in point is Germany where SMEs account for more than 85\% of GDP (German Economic Report, 2015).

Globally small and medium size enterprises account for over eighty percent (80\%) of business and more than fifty percent employment in the European Union (Mandl, 2013). According to Kenya Vision 2030 (2003) the country can

Corresponding Author:-Justice J. Mutua Nzioki.

Address:-School Of Business and Economics, Mount Kenya University. 
only achieve macroeconomic stability by supporting and incubating SMEs. The government endeavours to develop SME parks full with the relevant services and infrastructure to make them viable (Kenya Vision 2030, 2007).

Macroeconomic stability is key for economic recovery and rapid growth and this has been witnessed since 2003. Through the policy, technical and financial support given to SMEs by the Kenyan government, Kenya's economy has grown significantly.

According to the United Nations Millenium Declaration Goals (SDG) (2015), SME growth will aid in promoting sustainainable development while improving the quality of everyone. This is a major strategy to ending poverty and ensures that all human beings are in a position of enjoying a prosperous and fulfilling live (SDGS, 2030). Previously, researchers have centred research on issues affecting large corporations and this has left a remarkable gap on issues surrounding SMEs with very scarce relevant literature.

With the Kenyan government pledging over one million jobs every year, it is certain that these jobs will be in the SME sector (Jubilee Alliance Manifesto, 2013). According to the KEBS (2009), eight out of ten businesses close within five months of operation. The KEBS report also indicates that $90 \%$ of the two out of five SMEs that make it do not grow into a full blown corporation but rather remain within the SMEs sector for life. Very few of these SMEs grow to explore their full potential as many live to employ less than six people.

Determinants such as innovations and innovative strategies in totality have either been partially addressed or not addressed at all. The Kenyan government has put measures to strengthen SMEs and ensure they grow to be key industries tomorrow (Kenya Vision 2030, 2007). Previous governments have more or so made the same promise out of which nothing much has been achieved.

The challenge then becomes, why has this not been achieved? Are SMEs performing as anticipated? What are the factors inhibiting their growth? Is access to credit the only determinant to address or are there other major determinants worth noting and looking at? For these and many other reasons, the identification of the determinants of SME business growth is very important.

Against such a background the researcher notes that there is a gap in investing in innovative strategies and SME business growth that needs to be addressed. It is therefore important and of great necessity to examine how innovative strategies influence SME business growth in Gikomba Market, Nairobi County Kenya. Therefore the specific objective for this study was:

To assess the influence of innovative strategies on SME business growth in Gikomba Market, Nairobi County in Kenya

\section{Literature Review:- \\ Innovative strategies:-}

An exploratory study by Guzman (2010), on factors affecting SMEs in Pretoria South Africa notes that being innovative is a dominant survival tactic for SMEs as it encourages creativity and differentiation hence giving the business a competitive edge. The researcher also notes that innovative strategies are the best tool for dealing with change and gives the business the capacity to dealing with the changing business environment. The researcher highlights that deficiencies in innovative strategies is a leading cause of SME failure contributing to over $65 \%$ of failures in South Africa. Guzman recommends that organizations should encourage and invest in innovative strategies and personal accomplishment for continuous growth.

In a study about the sustainability of growth in SMEs in Kenya Colm O'Gorman (2015), explored human resource as a determinants of sustainable of growth but in his study he noted that innovative strategies are a major component of human resource. He noted that if employees are not innovative then they bring no added value into the business. A resourceful staff should offer solutions and undertake delegations successfully. The researcher recommends that creativity is as result of innovative strategies and should be encouraged. It is important that business investors take a look at the industry and take a bold change at all aspects of the business, from the clientele and product strategy to processes and achieving this will require appropriate innovative strategies (Carrie, 2008). 
In their research findings in Kenya Bowen et al., (2009), while studying the effect of policies on SMEs in Kenya concluded that most of the businesses sampled were less than three years old and the results suggested a high failure rate due to lack of creativity and innovative strategies. They noted that there was a lot of similarity between different business in terms of the products they offer, location and operational structure. None of the businesses exhibited a cost or product differentiation. The researcher recommends that investors should invest in niche markets that they understand and offer unique products and services thus gaining a competitive advantage.

\section{Knowledge Gap:-}

Most of the research carried out locally and abroad regarding SMEs focuses on issues to do with finance, policies and structures. Issues such as investing in innovative strategies as well as coming up with innovative strategies and innovations have been narrowly approached. There is scarcity of literature touching on innovative strategies and SME business growth. Available literature has focused on issues affecting established corporations. That notwithstanding the scarce literature addressing SMEs fails to explain clear strategies on how to implement the identified determinants for effective growth.

This research focused on innovative strategies as determinants of SME business growth. There was very little literature or no literature at all as regards the framework for creating, evaluating and implementing innovative strategies in SME environments. Available theories do not explain the various measures for the variable they address. They fail to explain to what extent their variables affect the growth of SMEs. Unavailability of reliable and valid data about SME business growth in Gikomba market in Nairobi County, Kenya is a major concern. This research will help provide clear strategies on how to harness innovative strategies as a key-influencing determinant to SME business growth.

Schumpeter's theory highlights on the role of innovative strategies as prime mover of business growth. The theory fails to address on the type and level of innovative strategies needed for business growth. The theory assumes that financial institutions finance innovations but this is not the case in most innovative strategies. Most innovative strategies are incubated from within the organization. The theory basis innovative strategies as a result of one person but an innovation can be devised from a group's idea. This theory is one sided and is based on socialism thus ignoring the place of capitalism.

\section{Methodology:-}

Qualitative and quantitative methods were applied throughout this research. Numeric data which was converted to numbers and was generated using quantitative techniques. This method was precise and was used for purposes of analysing numeric data obtained from the questionnaires.

Qualitative methods were used to collect non numerical data through interviews by use of interview guides. The information gathered was analysed interpretatively, subjectively, and diagnostically. This method was used to analyse data collected from interviews.

The research employed descriptive survey aimed at investigating how training influences SME business growth. Descriptive research aided in depicting the participants in an accurate way. The basic features of the variables were described using descriptive statistics. Generalization of the research findings addresses the determinants of business growth for all SMEs in Kenya as the research environment comprises of all manner of businesses of which most were studied. The target population for this research was six hundred (600) SMEs. Nairobi-Kenya has the highest number of SMEs in the country (K-Rep, 2009). The target population for the research comprised of established SME such as second hand cloth vendors, vegetable vendors, kiosks/supermarkets, restaurants, clinics/chemists, tailors, metal works, shoe vendors and cobblers operating in Gikomba market in Nairobi County, Kenya.

The number of employees was used to determine the size of the business as a SME should contain not more than 50 staff (McCormick \&Pedersen, 2011). For purposes of this study, the target population was six hundred (600) SMEs operating in Gikomba. Multistage sampling technique was adopted to identify the target population. From each sampling frame, $20 \%$ of the population was selected by use of the proportionate sampling frame technique. Simple random sampling was used in selecting the exact individuals to participate in the. The duration, type of data to be collected and the research study objectives was considered in selecting the tools. 
Semi structured instruments were used in the study employing a mix of open and closed-ended questions. Questionnaires were simply administered through dropping and picking from the study sample population. Various tools were used to edit data for incompleteness and inconsistencies. Quantitative data was analysed using description statistics. Quantitative data was edited and analysed to supplement the qualitative data. The researcher made use of quantitative analysis by using statistical techniques such as tabulations and percentages for purposes of showing the frequency differences. The study utilizes quantitative analysis to analyse data. Data differences in frequencies will be presented by use of pie charts, percentages, frequency counts, tabulations and arithmetic means. In order to obtain credible results, the researcher used statistical tools such as SPSS (v21) to analyse.

\section{Results and Discussion:-}

The research findings, analysis and presentation details on the presentation of data collected form the filed, analysis of the same data using a variety of techniques and finally interpretation of the data to meaningful information. The sample size for the study was 120 respondents out of which only 101 were able to fill and return the questionnaire. The response rate turned out to be $84 \%$, which is still excellent. According to Mugenda and Mugenda (2011) a response rate above $50 \%$ for data analysis is good enough.

Analysis of Study Background Information:-

Table 1:-Type of Businesses in Gikomba

\begin{tabular}{|l|l|l|}
\hline Business Category & Number of respondents & Percentage (\%) \\
\hline Mitumba & 18 & $17.8 \%$ \\
\hline Restaurant/Hotels & 14 & $13.9 \%$ \\
\hline Vegetables & 11 & $10.9 \%$ \\
\hline Kiosks/Supermarkets & 8 & $7.9 \%$ \\
\hline Clinics/Chemists & 6 & $5.9 \%$ \\
\hline Tailors & 13 & $12.9 \%$ \\
\hline Metal Works & 10 & $9.9 \%$ \\
\hline Shoes & 12 & $11.9 \%$ \\
\hline Cobblers & 9 & $8.9 \%$ \\
\hline Total & $\mathbf{1 0 1}$ & $\mathbf{1 0 0 \%}$ \\
\hline
\end{tabular}

Period The Respondents Have Been in Business:-

The below Table 2 showcases the duration respondents have operated their business.

Table 2:-Business experience

\begin{tabular}{|l|l|l|}
\hline & Frequency & Percentage (\%) \\
\hline 5 Years and below & 12 & $11.9 \%$ \\
\hline Between 6-10 Years & 42 & $41.6 \%$ \\
\hline Between 11-15 Years & 36 & $35.6 \%$ \\
\hline 16 Years and above & 11 & $10.9 \%$ \\
\hline Total & $\mathbf{1 0 1}$ & $\mathbf{1 0 0 . 0 \%}$ \\
\hline
\end{tabular}

From the information generated above it is evident that $11.9 \%$ of the respondents have operated their business for 5 years and below. $41.6 \%$ have operated for between 6-10 years. A further $35.6 \%$ have run their venture for between 11-15 years where as last but not least $10.9 \%$ have operated for 16 years and above.

\section{Influence of Innovative Strategies On SME Business Growth:-}

The researchers in this section sought to know the influence of various innovative strategies and techniques on SME business growth in Gikomba market. The study findings are as follows: 
What influenced you to starting your:-

Table 3:-Influence to starting business

\begin{tabular}{|l|l|l|}
\hline & Frequency & Percentage (\%) \\
\hline Market presence & 37 & $36 \%$ \\
\hline Joblessness a new & 52 & $52 \%$ \\
\hline \begin{tabular}{l} 
To bring a $\begin{array}{l}\text { innovation } \\
\text { Family business }\end{array}$ \\
\hline Total
\end{tabular}$\quad 10$ & $10 \%$ \\
\hline
\end{tabular}

The research study found out that $36 \%$ of the respondents started their business because of availability of market. A majority $52 \%$ started their business out of joblessness. $2 \%$ wanted to bring new innovations into the market where as $10 \%$ just joined their family business.

Areas of the SME that use technology:-

Table 4:- Areas of the business that use technology

\begin{tabular}{|l|l|l|}
\hline & Frequency & Percentage (\%) \\
\hline In production process & 20 & $19.7 \%$ \\
\hline In purchasing & 34 & $33.7 \%$ \\
\hline In distributing products & 14 & $13.9 \%$ \\
\hline In payment process & 33 & $32.7 \%$ \\
\hline Total & $\mathbf{1 0 1}$ & $\mathbf{1 0 0 \%}$ \\
\hline
\end{tabular}

$19.7 \%$ confirmed to have used technology in production processes. A majority 33.75 used it in purchasing. Another $13.9 \%$ used technology in distributing their products where as $32.7 \%$ used it in payment processes.

Ability to develop new products and bring to the market:-

Table 5: Brought new products to the market

\begin{tabular}{|l|l|l|}
\hline & Frequency & Percentage (\%) \\
\hline Yes & 68 & $67.3 \%$ \\
\hline No & 33 & $32.7 \%$ \\
\hline Total & $\mathbf{1 0 1}$ & $\mathbf{1 0 0 \%}$ \\
\hline
\end{tabular}

A majority $67.3 \%$ of the respondents confirmed to have brought new products into the market where as $32.7 \%$ indicated that they have not brought any new products into the market.

Effect of new product development on business growth:-

Table 6:- Effect of new product development on business growth

\begin{tabular}{|l|l|l|}
\hline & Frequency & Percentage (\%) \\
\hline Greatly & 36 & $35.6 \%$ \\
\hline Moderately & 20 & $19.8 \%$ \\
\hline Don't know how & 12 & $11.9 \%$ \\
\hline Total & $\mathbf{6 8}$ & $\mathbf{6 7 . 3 \%}$ \\
\hline
\end{tabular}

A majority $35.6 \%$ out of the $67.3 \%$ that brought new products in the market indicated that it greatly impacted their business growth. $19.8 \%$ confirmed that it moderately impacted their business growth where as $11.9 \%$ indicated that they did not know how it impacted their business growth.

Presence of new strategies for business growth and operations:-

Table 7:-New strategies in operation

\begin{tabular}{|l|l|l|}
\hline & Frequency & Percentage (\%) \\
\hline Yes & 56 & $55.4 \%$ \\
\hline No & 45 & $45.6 \%$ \\
\hline Total & $\mathbf{1 0 1}$ & $\mathbf{1 0 0 \%}$ \\
\hline
\end{tabular}

The study confirmed that a majority $55.4 \%$ had realized new strategies in their business operations where as a minority $45.6 \%$ had not brought any new strategies into their business. 
Effect of new business strategies on the SME business growth:-

Table 8:-Influence of new strategies on business growth

\begin{tabular}{|l|l|l|}
\hline & Frequency & Percentage (\%) \\
\hline Greatly & 36 & $35.6 \%$ \\
\hline Moderately & 13 & $12.9 \%$ \\
\hline Don't know how & 7 & $6.9 \%$ \\
\hline Total & $\mathbf{5 6}$ & $\mathbf{5 5 . 4 \%}$ \\
\hline
\end{tabular}

A majority $35.6 \%$ out of the $55.4 \%$ of those who had new strategies in operation confirmed that new strategies greatly impacted their business growth. $12.9 \%$ indicated that indicated that new strategies moderately impacted their business their growth. A minority $6.9 \%$ did not know how it impacted their business growth.

Availability of a business plan:-

Table 9:-Presence of a business plan

\begin{tabular}{|l|l|l|}
\hline & Frequency & Percentage (\%) \\
\hline Yes & 65 & $67.3 \%$ \\
\hline No & 33 & $32.7 \%$ \\
\hline Total & $\mathbf{1 0 1}$ & $\mathbf{1 0 0 \%}$ \\
\hline
\end{tabular}

The study confirmed that a majority $67.3 \%$ used a business plan where as a minority $32.7 \%$ did not have any business plan.

Effect of a business plan on SME business growth:-

Table 10:-Effect of business plan on business growth

\begin{tabular}{|l|l|l|}
\hline & Frequency & Percentage (\%) \\
\hline Greatly & 42 & $43.5 \%$ \\
\hline Moderately & 19 & $19.7 \%$ \\
\hline Minimal effect & 4 & $4.1 \%$ \\
\hline Total & $\mathbf{6 5}$ & $\mathbf{6 7 . 3 \%}$ \\
\hline
\end{tabular}

A majority $43.5 \%$ of the respondents who confirmed to have a business plan indicated that it impacted their business greatly. $19.7 \%$ indicated that it moderately impacted their business where as a minority $4.1 \%$ confirmed that it had no impact to their business growth.

Presence of business competition:-

Table 11:-Presence of competition

\begin{tabular}{|l|l|l|}
\hline & Frequency & Percentage (\%) \\
\hline Yes & 81 & $80.2 \%$ \\
\hline No & 20 & $19.8 \%$ \\
\hline Total & $\mathbf{1 0 1}$ & $\mathbf{1 0 0 \%}$ \\
\hline
\end{tabular}

A majority $80.2 \%$ confirmed to experience competition in their business. A minority $19.8 \%$ indicated that they did not face any competition in their business.

Influence of competition on SMEs business growth:-

Table 12:- Influence of competition on SME business growth

\begin{tabular}{|l|l|l|}
\hline & Frequency & Percentage (\%) \\
\hline Greatly & 49 & $48.5 \%$ \\
\hline Moderately & 21 & $20.8 \%$ \\
\hline Minimal influence & 11 & $10.9 \%$ \\
\hline Total & $\mathbf{8 1}$ & $\mathbf{8 0 . 2 \%}$ \\
\hline
\end{tabular}

Out of the $80.2 \%$ of respondents who confirmed to experience competition, a majority $48.5 \%$ indicated that it influenced their business growth greatly. $20.8 \%$ indicated that it had a moderate influence to their business growth where as a minority $10.9 \%$ confirmed that it had no influence to their business growth.

Presence of a competitive advantage and differentiation over competitors:-

Table 13:-Presence of business competitive advantage

\begin{tabular}{|c|c|c|}
\hline & Frequency & Percentage (\%) \\
\hline Yes & 39 & $38.6 \%$ \\
\hline
\end{tabular}




\begin{tabular}{|l|l|l|}
\hline No & 62 & $61.4 \%$ \\
\hline Total & $\mathbf{1 0 1}$ & $\mathbf{1 0 0 \%}$ \\
\hline
\end{tabular}

The study confirmed that a minority $38.6 \%$ had a competitive advantage where as a majority $61.4 \%$ did not.

Effect of the competitive advantage on the SME business growth:-

Table 14:-Influence of competitive advantage on SME business growth

\begin{tabular}{|l|l|l|}
\hline & Frequency & Percentage (\%) \\
\hline Greatly & 17 & $16.9 \%$ \\
\hline Moderately & 16 & $15.8 \%$ \\
\hline Minimal influence & 6 & $5.9 \%$ \\
\hline Total & $\mathbf{3 9}$ & $\mathbf{3 8 . 6 \%}$ \\
\hline
\end{tabular}

Out of the minority $39 \%$ with a competitive advantage, a majority $16.9 \%$ confirmed it influenced their business growth greatly. $15.8 \%$ indicated that it influenced their business growth moderately where as $5.9 \%$ indicated that it did not affect their business growth.

\section{Discussion of Research Findings:-}

Influence of Innovative Strategies on Smes Business Growth in Gikomba Market, Nairobi County in Kenya:On the influence of innovative strategies on SME business growth, the respondents indicated that they used ICT innovations in product payments, distribution and purchasing. This is consistent with (Guzman 2010), that application of ICTS tools is business processes is a dominant tactic for SMEs growth and survival and that encouraging creativity and differentiation gives the business a competitive advantage. Continuous innovation was evident in the study and businesses that continuously innovated presented a continuous positive business growth, which is consistent Colm O'Gorman (2011), who noted that continuous innovation should be a major component of human resource in SMEs as it ensures solid business plan thus giving the business a competitive edge. These study findings realized that a competitive advantage greatly influence business growth. The findings are consistent with Bowen et al., (2009), who while studying the effect of policies on SMEs in Kenya concluded that most of the businesses sampled were less than three years old and the results suggested a high failure rate due to lack of creativity and innovative strategies.

\section{Conclusions and Recommendations:-}

The study noted that innovative strategies are key to SME business growth. It is through innovations that new products and services can come into the market. The respondents who had innovative strategies in place outperformed their less innovative strategy oriented colleagues. They posted better business performance thus business growth. Majority of the respondents seemed to practice business similar to each other therefore did not posses any competitive advantage that would give them an edge in the market.

\section{Recommendations:-}

Recommendations for Practice to SME Operators and Other Stakeholders:-

Innovative strategies are the key to business differentiation, competitive advantage and new product innovations and development. There is a great need for the society and the government to create an ambient environment where innovations thrive. Innovative policies and availability of capital to fund innovation will play a big role in incubating innovations thus boosting SME business growth.

\section{Recommendations for Further Research in This Field Of Study:-}

The study focused on innovative strategies influence on SMEs business growth in Gikomba market. It would be prudent to look at other determinants that also have a notable influence on SME business growth not only in Nairobi but also in the country at large.

The researcher also recommends that another study to be done in the future and determine whether the suggested findings and measures in this study were implemented and if there are any gaps, how can they be filled? Through nurturing and promoting SMEs their business growth is assure and the future will be brightly guaranteed. 


\section{References:-}

1. Asma, B. (2015). Factors Affecting SMEs in Algeria. Algiers.

2. Bowen, M., Makarius, M., \& Mureithi, S. (2009). Management Of Business Challenges Among Small And Micro Enterprises In Nairobi-Kenya. Journal Of Business Management.

3. Coad, A. (2009). Firm growth. A survey of papers on economics and evolution, pp. 1430-4716.

4. Colm, O. (2015). The sustainability of growth in small- and medium-sized enterprises. International Journal of Entrepreneurial Behaviour\& Research , 7 (2), 60-75.

5. Fida. (2008). The Importance of Small and Medium Enterprises (SMEs) in Economic Development . Banking, Finance and Accounting Community.

6. Germany Trade and Invest. (2015). Enonomic Overview Germany. Berlin: Government of Germany.

7. Government of Kenya. (2008). Kenya Vision 2030. Nairobi: Government Printer.

8. GoG. (2014). German Economic Report. Government Printer.

9. Guzman, (2010). Factors Affecting the Growth of SMEs in Pretoria. South Africa.

10. Inter-Agency and Expert Group on MDG . (2015). The Millennium Development Goals Report . Department of Economic and Social Affairs Secretariat. New York: United Nations.

11. Jubilee Alliance Party. (2013). Transforming Kenya - Securing Kenya's Prosperity. Nairobi: Kenya Jubilee Alliance Coalition .

12. K-Rep; Centum Group. (2015). Annual Report. Nairobi: Centum Investments.

13. Kenya Bureau of Standards. (2009). Kenya Bureau of Standards Annual Review Report. Nairobi: Government Printer.

14. Kinyua, A. N. (2014). Factors Affecting the Performance of Small and Medium Enterprises in the Jua Kali Sector In Nakuru Town. Kenya Egerton University Nakuru.

15. Mandl, M. (2013). Overview of family business relevant issues. Vienna: Austrian Institute for SME Research.

16. McCormick, \& Pedersen . (2011). Small enterprises. (U. o. Nairobi, Ed.) Copenhagen : Institute for Development Studies (IDS), University of Nairobi and Centre for Development Research (CRD) .

17. Mugenda, M. O., \& Mugenda. (2011). Research Methods. Nairobi: Acts Press.

18. Mwania, M. (2011). The effect of Biashara Boresha Loan on Performance of Micro and Small enterprises owned by KCB Ruiru branch customers.

19. Weber, M., \& Parsons, T. (1950). Modernization Theory.

20. World Bank. (2015). Small Business Enterprises: A framework for intervention. The World Bank Economic Report.

21. World Bank Group. (2015). Economic Report: Financing the Post-2015 Sustainable Development Agenda.

22. Vicere, A. A. (2010). Executive education and strategic imperatives: A formula for crafting competitiveness. American journal of management Development , 1 (2), 31-36. 